\section{PERAN BAGIAN HUMAS SEKRETARIAT DAERAH KABUPATEN MAMASA DALAM PENYEBARAN INFORMASI PUBLIK}

\author{
${ }^{1}$ Seniwarni*, ${ }^{2}$ Dahrul Saharuddin, ${ }^{3}$ Masyhadiah \\ Program Studi Ilmu Pemerintahan \\ Fakultas Ilmu Sosial dan Ilmu-Ilmu Pemeritahan \\ Universitas Al Asyariah Mandar
}

Corresponding author

seniwarni073@gmail.com

\begin{abstract}
Abstrak
Penelitian ini bertujuan mengetahui peran bagian humas sekretariat daerah Kabupaten Mamasa dalam penyebarluasan informasi pembangunan daerah, serta hambatan yang dihadapi oleh bagian humas sekretariat daerah Kabupaten Mamasa dalam penyebarluasan informasi pembangunan daerah. Metode yang digunakan, yaitu deskriptif kualitatif. Pengumpulan data dilakukan dengan teknik observasi dan wawancara mendalam Penelitian diksanakan di bagian Humas Kantor Sekretariat Daerah Kabupaten mamasa. Hasil penelitian menunjukkan bahwa penyebaran informasi pada bagian Humas Sekretariat Daerah Kabupaten mamasa dilakukan melalui mekanisme kerja yang belum terintegrasi dengn baik maka dalam menjalankan fungsi dan perannya masing- masing dalam operasional penyebaran informasi terkadang tidak sesuai dengan apa yang ditegaskan dalam uraian tupoksi. Ketersediaan sumber daya manusia merupakan suatu faktor yang mendukung pelaksanaan kegiatan penyebaran informasi.
\end{abstract}

Kata Kunci: Peran, Fungsi Penyebaran Informasi; Hubungan masyarakat
Keywords: Role, Information Dissemination Function; Public relations
Article history

DOI: http://dx.doi.org/10.35329/ip.v2i2.1509

Received: 12 Agustus 2020 | Received in revised form: 30 September 2020 | Accepted: 22 Oktober 2020 


\section{PENDAHULUAN}

Saat ini berkembangnya teknologi yang semakin canggih sekarang ini, dengan kemejuan mekanisme informasi yang baik dan perkembagan. Beberapa informasi yang ada sekarang ini sudah bisa diketahui bahwa informasi sudah menjadi komsumsi public didalam suatu kebutuhan di dalam kehidupan masyarakat. Baik itu didalam kebudayaan. Sosial, pembagunan, terutama dalam segi perekonomian. Baik bagi masyarakat, media juga penting untuk medukung peningatan evisien dalam produktivitas suatu instansi, oleh karna itu sistem informasi saat ini dirancang atau diarahkan sebagai alat penunjang untuk perencanaaan pembagunan.

Dalam ketentuan yang diterbikan dalam pelaksanaan undang-udangan sebagai keterbukan sistem informasi publik melalui uu pengetahuan sistem informasi public (kip) tahun 2008 nomor 14, dalam bunyinya mengatakan "keterbuka informasi public adalah prasarana untuk keikutsertaan peningkatan public dengan memberikana penyelenggaraan serta pengawasan terhadap birokrasi yang berakibat untuk mementingan kepentigan public, dalam upaya penyebarluasan informasi public serta membuka tranparansi kepada masyarakat luas dan yang terpenting untuk penyebarluasan informasi yang bertujuan untuk pembagunan daerah dan meberikan informasi secara intern maupun ekstern.

Untuk menyeberluaskan informasi public salah seorang ahli memberikan penjelasan dan berpendapat dalam buku yang diterbikan hubungan masyarakat modern oleh bonas s.k,

"dalam upaya memberikan pelayanan informasi mengenai problem yang terjadi saat sekarang ini dan upaya agar bisa di ketahui orang banyak maka informasi harus mempunyai nilai berita, dengan maksud untuk menambah perhatian terhadap suatu tempat, orang, sebab atau suatu institute, yang biasanya terdapat dalam cetakan umum."

Pemerintah melali humas akan memberikan kebijakan dan menjelaskan tentang cara melakukan pembangunan. Di karenakan bagaian humas dituntut untuk bertidaka sebagai penyebar infomasi dalam meningkatkan penyebarluasan infor masi di kabupaten dengan cara menjalankan program yang sudah direncanakan demi upaya mensejatrahkan masyarakat serta memberikan pemahaman agar tidak memberikan kekeliruan dana pelaksanaan penyebarluasan informasi, dan dalam melancar hal tersebut perlu kerja sama antara pemerintah daerah dan pemerintah provinsi serta media massa yang berada di daerah tersebut untuk saling bekerja sama demi melancarkan pelaksanan dalam upaya peningkatan penyebarluasan public.Dan yang dapat dilakukan dalam upaya menyebarluaskan informasi public dengan cara mengunakan media elektronik serta media cetak yang ada di daerah setempat dan dalam keterbukan memberikan informasi kepada msyarakat yang dapat memberikan kepercayaan bagi pemerintah dalam upaya mengoptimalkan penyelenggaran serta pengawasan dalam melakaukan pemberian informasi dan memberikan pelayanan kepada masyarakat agar masyarakat sadar akan penting informasi yang akan di berikan dan ikut membantu melakukan penyebarluasan informasi secara tidak langsung kepda semua penduduk.

Sebagai kabupaten yang ada di provinsi sulawesi yang sedang genjar-genjarnya melaksanakan perbaikan di berbagai bidang, untuk bertujuan meningkatkan pemerintahan yang baik maka pemerintah daerah dalam hal ini harus memiliki media informasi demi menjalan kan semua program yang akan dilaksanakan, dan untuk menghindari problem yang akan terjadi apabila dalam memberikan informasi tidak sesuai dengan apa yang akan dilaksanakan dan menimbukan respon negatip kepada pemerintah daerah, pemerintah bertidak pemberi informasi melalui bagian humas sudam membuat website resmi untuk memberikan informasi kepada masyarakat secara terbuka dan memanfaatkan media-media yang ada di kabupaten mamasa dalam penyebar luasan informasi public.

Dengan adanya bagian humas di sekertariat kabupaten mamasa yang begitu penting dalam melaksanakan good governance, peningkatan penyebarluasan informasi publik dala melakukan pembangunan, informasi baik guna mendapatkan kepercayaan dari masyarakat demi terlaksananya keterbukaan informasi sebagai media penghubung kepada masyarakat agar terlaksananya program yang telah di siapakan dala upaya membangun pemerintahan yang baik.

Berdasarkan hal tersebut, peran bagian humas sangat perlu untuk menjalankan informasi yang telah dirancang untuk menekan opini public yang ada mengenai respon yang tidak benar di dalam pelaksanan pembangunan sehingga dalam melakukan penyebarluasan informasi public dan berjalan dengan sempurna tampa ada hambatan atau kendala yang di hadapai oleh pemerintah daerah serta menjadi mendia yang sangat di butukan.

Dalam mekanisme pemberian informasi yang tepat maka membutuhkan rancagan atau program yang memberikan manfaat bagi masyarakat yang dapat menjadi pengikatan dalam upaya penyebarluasan infomasi public, dan agar tidak mendapat hambatan dalam melakukan penyebarluasan informasi public kita perlu memberikan pemahan tentang informasi yang akan di berikan kepada masyarakat agar nanti tidak menjadi masalah dalam melakukan perencanaan atau pelaksanaan penyebarluasan informasi di kabupaten mamasa.

\section{Pengertian Humas}

Pada umumnya masyarakat dalam teori kehumasan pemerintah pada setiap instansi dalam rangka penyebaran aktivitas keluar maupun kedalam merupakan suatu keharusan pemerintah dalam unit kehumasan, teori kehumasan ini dijelaskan dalam Widjaja (1993:63). Media interaksi yang digunakan 
dalam memperlancar interaksi melalui media pers, media radio dan media televise serta media lainnya.

Humas pemerintah lebih menekankan pada servis public agar pelayanan umum dapat meningkat, dalam unsur komersial humas pemerintahan melakukan kegiatan dalam hal yang sama melalui media promosi, publikasi dan periklanan. Dalam media tersebut humas pemerintahan memberikan dan menjelaskan informasi tentang tindakan dan kebijaksanaan masa jabatannya sesuai dengan perbedaan dari fungsi dan pokok humas yang ada diruang lingkup humas pemerintahan.

\section{Karakteristik Humas}

a) Komunikasi yang bersifat dua arah Komunikasi yang bersifat dua arah akan memungkinkan terjadi informasi tumpang tindih namun pada hakekatnya humas merupakan ruang lingkup dalam hal menyampaikan informasi tetapi sebaliknya dalam menyampaikan informasi belum bisa dikatakan sebagai humas. Sebagai humas dalam artian komunikasi dapat menyebabkan terjadi hubungan yang saling tumpang tindih. Oleh karena itu usaha yang mungkin dilakukan agar tidak terjadinya hubungan yang tumpang tindih seperti membuat kotak saran yang ditempel di dinding dekat pintu masuk. Dan juga cara agar tidak terjadinya hubungan yang tumpang tindih cara berkomunikasi harus secara langsung tanpa adanya pihak ketiga seperti komunikasi pada saat dalam acara rapat, forum bebas dan pertemuan lainnya yang tidak ada pihak ketiga atau penghubung (Kusumastuti, 2002:15).

b) Adanya sifat terencana Adanya sifat terencana dalam kegiatan kerja humas sangatlah penting karena dimana hasil kerjanya mempunyai hasill. Oleh sebab itu suatu kerja manajemen atau fungsi manajemen adalah humas.Ukuran keberhailan dari suatu tugas Humas membutuhkan perencanaan sebagai aksi ujian dari aktivitas yang dilakukan sehingga humas dapat dikatakan sebagai penyihir yang mampu membuat hitam jadi putih untuk mencapai keberhasilan yang dibutuhkan. Pendapat ini diungkapkan oleh (Kusumastuti, 2002:16). Humas dalam penerapannya tidak cenderung dalam integrasi dibagian lain. Berorientasi pada organisasi atau lembaga sehingga banyak kalangan yang merasa bahwa humas mempunyai kerja yang sulit sehingga orang banyak mengatakan bahwa humas tidak mempunyai manfaat untuk lembaga dan organisasinya. Penrapan yang salah membuat humas itu sendiri tidak dianggap hasil kerjanya.

Tujuan utama dari humas merupakan kondisi yang harus dimiliki dari lembaga kehumasan sehingga tujuan dari visi misi dari lembaga tersebut dapat mendukung dengan mempunyai tujuan yang sama.

c) Public merupakan sasarannya (Kusumastuti, 2002: 16) arti dari relations publik menjadikan masyarakat dalam arti social agar dapat membedakan letak daripada interen sehingga membuat sasaran hukum bukanlah perorangan melainkan sebagai kelompok dalam hubungan masyarakat yamg memiliki karakter sama dengan lainnya agar bisa dikatakan penyebab adanya orang mempunyai istilah hubungan relasi.

\section{Fungsi Humas}

Adapun fungsi humas Menurut Edward L. Bernay dalam Ruslan (2016: 18) yang membagi fungsi humas kedalam 3 bagian yaitu sebagai berikut:

- Memberikan penjelasan kepada masyarakat.

- Secara langsung masyarakat melaksanakan perbuatan yang bisa merubah sifat.

- Dalam hal integrasi antara perbuatan dan sikap masyarakat harus mengupayakan perbuatan dan sikap dalam lembaga dan begitupun sebaliknya.

\section{Petugas Humas berperan}

Adapun peran petugas humas menurut kusumastuti (2002:24-25) peran dibagi menjadi dua, yang pertama adalah peran teknis dan yang kedua adalah peran managerial. Sebagaimana yang diketahui bahwa peran teknis dapat di jelaskan sebagai berikut yakni:

\section{1) Expert Preciber Communication}

Sebagai seorang petugas disini hubungan diumpamakan sebagai jalinan antara peserta didik dan guru, dimana seorang guru memberi nasihat kepeda peserta didiknya.

2) Penyambung dalam pemecahan masalah Sebagai penyambung dalam pemecahan masalah fungsi peran sebagai fasiltas penyambung yaitu membuat para petugas terlibat dalam organisasi jika dimungkinkan jadi pemimpin untuk menangani manajemen yang krisis.

3) Fasilitas komunikasi

Dalam penyambung fasilitas komunikasi kepada public dan masyaraka, serta menjadi fasilitas untuk menangani kesalahpahaman komunikasi. Sebagai fasiltas komunikasi antara organisasi atau public berperan penting terhadap kepentingan umum.

4) Teknik komunikasi

Dalam hal pelaksana teknis komunikasi disini diharap untuk melaksanakan komunikasi dalam menyiapkan pelayanan manajemen petugas dalam melaksanakannya.

\section{Humas tugas}

Suatu organisasi yang mempunyai hubungan dengan fungsi umas memiliki tiga dalam tugasnya. Adapun tugas dari humas tersebut dapat dilihat yaitu dalam (Kusumastuti, 2002: 25-26):

- Analisis, mengevaluasi serta mengiterpretasikan cenderung ke tingkah laku public, yang dapat rekomendasi kepada maajemen dalam membuat peraturan dari suatu lembaga yang cenderung baik dihadapan public hal dijelaskan Frank Jeffkins yang dibagi atas empat situasi yang sering dihadapi oleh humas yaitu, memusuhi,, prasangka, apatis dan tidak tahu.berangkat dari pada situasi yang dihadapi public yang bermusuhan jadi teman, prasangka jadi 
terima, cuek jadi acuh, serta yang tidak tahu menjadi tahu.

- Organisasi dalam mempunyai keinginan jauh tidak sama seperti keinginan publik begitupun kebalikannya. Tetapi Mempertemukan keinginan lembaga dan keinginan publik juga bisa sedikit mengalami perbedaan terhadap keinginan ini bahkan juga dapat mempunyai kesamaan. Maka humas dapat bertugas untuk menghubungkannya ke dalam situasi apapun, kepentingan dari humas yang mempunyai tugas ini yaitu menemukan bila keinginan dianggap berbeda dalam pelaksanaanya.

- Dalam tugas humas memonitoring tugas dari semua program yang bisa mengevaluasi sebagai hal yang mensyaratkan humas dalam memberi ataukah diberhentikan.

\section{Humas Mempunyai urusan}

Urusan dalam humas menurut fungsi serta perannya secara keseluruhan merupakan bagian dari urusan humas secara keseluruhan. Hal ini diungkapakan Kusumastuti (2002;27) bahwa:

\section{Program Humas}

Sesuai dengan program humas yang diungkapakan oleh Widjaja (1993: 61), dimana humas sebagai sesuai dengan peran humas sebagai documenter, mediator antara pimpinan dengan publik dan sebagai sarana untuk melayani kepentingan umum. Yang dititik beratkan pada program humas.

1. Sebagai pelayanan program

Dalam hal ini program pelayanan yaitu lisan dengan tulisan.

2. Sebagai mediator program

Sebagai penyelenggara konfrensi pers, wisata pers, Program ini berupa cara pegawai membaca jawaban surat yang dikirim, membuat tanggapan tentang wacana yang tidak baik dan lain sebagainya.

3. Sebagai documenter program

Isi dalam documen ini seperti transkrip pidato, rekaman foto, pembuatan dokumentasi film dan lain sebagainya.

\section{Pengertian Peran}

Peran lebih banyak berpatokan terhadap proses penyesuain diri sehingga bisa diartikan bahwa peran merupakan lembaga struktur social yang penting bagi artinya.

Peran merupakan suatu bagian yang jadi pegangan bagi pimpinan dalam suatu hal atau peristiwa yang apabila disimpulkan peran menjadi tanggung jawab yang dimiliki seseorang dalam melaksanakan suatu kegiatan. Poerwadarminta (2004: 43)

Sedangkan Soeharto (2002;118) yang berpendapat bahwa peran adalah kedudukan seseorang terhadap hak dan kewajibannya dalam menjalani peran terhadap suatu aspek yang dinamis.

Lain hal yang diungkapkan oleh Usman (2001: 4) yang mengatakan bahwa terciptanya suatu peranan yang saling mengaitkan dalam situasi tertentu yang berhubungan dengan berubahnya tingkah laku menciptakan beberapa rangkaian proses.

Lebih lagi Nasution (2005: 74) menambahkan arti peranan meliputi hak dan kewajiban yang saling berkaitan. Lebih lanjut Setyadi (2012: 29) mengemukakan pendapatnya bahwa peranan ialah pola yang abstrak namun memiliki aspek dinamis dalam status organisasi yang mempunyai tindakan konkrit.

\section{Informasi yang disebarkan melalui peranan humas}

Humas di dalam menjalani perannya berdasarkan fungsi dan perannya sering berusaha agar kemauan dari lembaganya dapat tercapai sesuai informasi yang yang dinginkan oleh lembaga atau organisasi. Aktivitas yang dilakukan dalam memberikan informasi publik kepada masyarakat harus diketahui berapa lama dan untuk apa informasi tersebut dipublikasikan.

\section{METODE PENELITIAN}

Jenis penelitian deskriptif kualitatif yang memusatkan masalah atau fenomena yang terjadi pada saaat penelitian di lakukan, kemudian memberi ata mengambarkan factual dengan cermat gambaran secara cermat dan faktual. Penulis menggambarkan atau melukiskan keadaan objek penelitian berdasarkan fakta yang ada mengenai implementasi kinerja Humas Sekretariat Daerah Kabupaten Mamasa dalam penyebaran informasi publik.

Dengan demikian akan menekankan persoalan (kualitas). Didalam melakuakan penelitian ini kualitatif dapat berubah kapan saja sehingga keberhasilan dalam penelitian ini akan sangat memuaskan.

\section{Defenisi Operasional dan Variabel}

Dari uraian beberapa konsep yang berhubungan erat dalam penelitian ini dan demi mempermudah pencapaian yang didusun dalam defenisi oprasional sebagai pendoman penelitian ini sebagai mana yang di maksud.

Peran bagian humas dalam penyebaran informasi publik bertujuan untuk memenuhi kebutuhan dan keinginan masyarakat. Yang ingin mengetahui ianformasi yang telah terjadi dan tugas sebenarnya bagian humas adalah menimplementasikan tugas humas untuk mencapai peran serta fungsi yang sebenarnya

a. Human Relations: merupakan satu peran antara sesama manusia yang dimana bertujuan untuk memberikan sifat, watak, keperibadian, tingakah laku serta sifat yang lainnya dalam aspek pemikiran yang menjadi pola hidup setiap manausi.

b. Media Relations: adalah strategi untuk membantuk seseorang dalam berkomunikasi relation professional public untuk menjaga komunikasi dari berbagai media, karena untuk membangun reputasi yang baik untuk masyarakat dan menjadi acuan dalam pergerakan atau tindakan yang sesuai dengan meningkatkan perusahan yang mempunyai reputasi baik, sehingga publing relation dapat menajadi penghung yang baik bagi pemerintah untuk 
masyarakat luas yang akan menciptakan pemerintahan baik di segala aspek didalam bidang masin-masing demi membangun hubungan yang baik

c. Public Speaking: iyalah komunikasi yang berbentuk lisan dengan menentukan sebuah topic dalam menyampaiaan informasi kepada masyarakat dan bertujuan memberikan pemahaman, mendidk serta mengajar kepada masyarakat tentang kondisi yang ada saat ini.

\section{Informan Penelitian}

Dari pendapat Sugiyoni (2016:82) ada dua teknik sampling yang bisa dilakaukan dengan cara sebagai berikut:

> Probablity Sanpling Probablity Sanling dimana dalam menganbil data dalam upaya mendapakan hasil yang diperlukan dari sbarbagai pihak atau anggota yang menjadi informan penelitian ini harus mengunakan random sanping, proportionte stratifd random sanpling, diproportionate stratifis random sanpling area (cluser).

$>$ Non Probability Sampling sebagai cara mengambil data atau sampel guna tidak memberikan kesempatan atau kebebasan untuk unsur populasi anggota yang menjadi informan dalam penelitian ini dan teknik ini meliputi purposive, jenuh snowball serta kuata aksindental dan sistematis sampling. Demi mancapai hasil yang maksimal.

Alasan menggunakan metode Purposive Sanpling karena sudah tidak memiliki karakter dengan sesuai fakta yang terjadi yang diteliti sekarang ini maka dari itu peneliti mengunak metode tersebut guna menentukan karakter-karakter yang terlebih dahulu dipunyai oleh informan yang akan dimintai informasi.

Untuk menentukan informan mengenai Peran Humas Sekretariat Daerah Kabupaten Mamasa Dalam Dalam Penyebaran Informasi Public. Adapun informan penelitian di kantor Sekretariat Daerah Bagian Humas Kabupaten Mamasa :

Tabel 3.1. Informan Penelitian

\begin{tabular}{|l|l|l|}
\hline \multicolumn{1}{|c|}{} & \multicolumn{1}{|c|}{ Informan } & \multicolumn{1}{c|}{ Jabatan } \\
\hline. & $\begin{array}{l}\text { KRDIANSA S.STP } \\
\text { SEMBE S.STP KOTONG }\end{array}$ & $\begin{array}{l}\text { Sekda Kabupaten } \\
\text { Mamasa } \\
\text { Mamasa }\end{array}$ \\
\hline & $\begin{array}{l}\text { TIMOTIUS Kabupaten } \\
\text { S.E }\end{array}$ & $\begin{array}{l}\text { Kabag Bagian } \\
\text { Humas Kabupaten } \\
\text { Mamasa }\end{array}$ \\
\hline. & $\begin{array}{l}\text { DEMMAELO S.E M.Si } \\
\text { S.Th MARANATHA }\end{array}$ & $\begin{array}{l}\text { Sub Bidang Protokol } \\
\text { Kabupaten Mamasa } \\
\text { Kabupaten Mamasa }\end{array}$ \\
\hline & HARTANTO SS.I & $\begin{array}{l}\text { Sub Bumas } \\
\text { Pemberitaan Dan } \\
\text { Dokumentasi }\end{array}$ \\
\hline & ELNA BOTTA S.E & Staf Humas \\
\hline & SOFIYAN S.IP & Staf Protokol \\
\hline & JON PAMPANG & Staf Dokumentasi \\
\hline
\end{tabular}

\section{Instrumen Penelitian}

Instrumen penelitian ini menerapkan metode deskriptip dengan mengunakan kualitatif. Digunakan berdasarkan pada kondisi dan masalah yang terjadi, Peran humas sekretariat daerah kabupaten mamasa dalam penyebaran informasi public. Bedasarkan peneliti akan membeikan pertanyaan langsung kepada informan yang menjadi kunci peelitian ini, dengan melakukan wawancara, kokumentasi, serta melakukan observasi.

\section{Teknik Pengumpulan Data}

Ada tiga Cara dalam mengumpulkan data yang akan menjadi bahan dalam penelitian ini sabagai kebutuhan penulis dengan cara; Wawancara mendalam, Observasi, dan Dokumentasi

\section{HASIL DAN PEMBAHASAN \\ Keadaan Geografis Kabupaten Mamasa}

Kabupaten yang berbatasan dengan kabupaten mamuju dan kabupaten polewali mandar terdapat di provinsi Sulawesi barat adalah kabupaten mamasa.

Letak wilayah kabupaten mamasa Secara geografis yaitu berada pada koordinat antara 119"- 49"119" 32" 27" BT, serta 2" 40" 00" - 03" 12" 00" LS. Dimana batas administrasinya dapat dilihat sebagai berikut yaitu :

a. Bagian utara mempunayi batasan dengan kabupaten mamuju

b. Bagian timur mempunyai batasan dengan kabupaten Tator

c. Bagian barat mempunyai batasan dengan kabupaten mamuju

Wilayah kabupaten mamasa mempunyai kedudukan yang berada di daerah pegunungan bagian timur Sulawesi barat. Dimana wilayah ini memiliki kesamaan dengan kabupaten Tator, sehingga kabupaten mamasa mempunyai jalur yang bagus untuk wisata dan budaya.

$3.005,88 \mathrm{~km}^{2}$ tahun 2006 merupakan luas wilayah dari kabupaten mamasa yang mengalami peningkatan kecamatan menjadi 15 kecamatan, 127 desa dan 39 desa untuk persiapan serta 11 kelurahan.

Peranan Humas di daerah kabupaten mamasa untuk penyebaran informasi publik

Dalam penyebaran informasi publik sangatlah penting. Dimana diketahui bahwa didalam repuutasi Bagian humas sendiri sangatlah berpengaruh untuk mendorong masyarakat dalam ikut serta berpartisipasi dalam pengelolaan masyarakat.

\footnotetext{
Hambatan yang Dihadapi oleh Bagian Humas Sekretariat Daerah Kabupaten Mamasa dalam Penyebarluasan Informasi Publik kepada masyarakat Ada beberapa maslalah yang menjadi menghambat humas Sekretariat Daerah Kabupaten Mamasa untuk penyebarluasan Informasi publik, yang berdampak pada pemerintah dalam membangun kepercayan masyarakat. Adapun pengaruh yang menjadi penghambat dalam penyebaran informasi publik di kantor secretariat daerah kabupaten mamasa yaitu
} 
anggaran dan kelengkapan peralatan, kurangnya pelaksanaan pelayanan dari pemerintah dan bebelitbelit serta birokrasi yang kaku.

a. Anggaran dan kelengkapan peralatan

Dalam menjalankan media informasi angaran serta peralatan sengat dibutuhkan dalam prose penyebarluasan informasi, karena tampa adanya anggara serta peralatan yang memada, bisa di pastikan dalam penyebaran iformasi tidak akan berjalan dengan maksimal.

b. Kurangnya pelayanan yang diberikan oleh pemerintah

Masyarakat di era informasi seperti sekarang ini menginginkan segala pengurusan lebih cepat, efektif, dan efisien. Itu sebabnya pelaksanaan pelayanan publik dituntut untuk dapat memberikan layanan yang prima. Untuk mewujudkan hal tersebut pemerintah dituntut untuk berbenah sebagai salah satu bentuk tanggungjawab terhadap masyarakatnya. Tetapi, perubahan tersebut ternyata tidak dapat berubah seketika, diperlukan rentang waktu bagi pemerintah dalam pelaksanaannya.

c. Pelayanan yang berbelit-belit

Pelayanan publik selalu dikaitkan dengan suatu kegiatan yang dilakukan seseorang atau kelompok orang atau instansi tertentu untuk memberikan bantuan dan kemudahan kepada masyarakat dalam rangka mencapai tujuan tertentu.

d. Birokrasi yang kaku

Birokrasi artinya kekuasaan, Birokrasi ini bersifat rigid atau kaku. Diartikan sebagai suatu organisasi yang memiliki rantai komando dengan bentuk piramida, dimana lebih banyak orang berada ditingkat bawah dari pada tingkat atas. Pada rantai komando ini setiap posisi serta tanggung jawab kerjanya dideskripsikan dengan jelas dalam organigram. Organisasi ini pun memiliki aturan dan prosedur ketat sehingga cenderung kurang fleksibel. Ciri lainnya adalah biasanya terdapat banyak formulir yang harus dilengkapi dan pendelegasian wewenang harus dilakukan sesuai dengan hirarki kekuasaan.

\section{DAFTAR PUSTAKA}

Abidin, Said Zainal. 2012. Kebijakan Publik. Jakarta: Salemba Humanika.

A.W, Widjaja. 1993. Komunikasi dan Hubungan Masyarakat. Jakarta: Bumi Aksara.

Elvinaro Ardianto. Handbook of Public Relations: Pengantar Komprehensif. Bandung: Simbiosa Rekatama Media, 2013, hlm. 262

Rosady Ruslan. Op. Cit. hlm. 227

Rachmat Kriyantono. Teknik Praktis Riset Komunikasi: Disertai Contoh Praktis Riset Media, Publik Relations, Advertising, Komunikasi Organisasi, Komunikasi Pemasaran. (Jakarta: Kencana, 2008), hlm. 27

Rahmat Kriyantono, Public Relation \& Crisis Management. Kencana Prenada Media, 2012.
Creswell, John W. 2014. Penelitian Kualitatif dan Desain Riset. Yogyakarta: Pustaka Pelajar

Effendy, Onong Uchjana. 1993. Human Relations Dan Public Relations. Bandung: Mandar Maju.

Gregory, Anne ed. 2004. Public Relations Dalam Praktik. Jakarta: Penerbit Erlangga.

Iriantara, Yosal. 2008. Media Relations: Konsep, Pendekatan dan Praktik. Bandung: Simbiosa Rekatama Media.

Kusumastuti, Frida. 2002. Dasar-Dasar Humas. Jakarta: Ghalia Indonesia.

Lattimore \& Baskin, Otis, et. al. 2010. Public Relations: Profesi dan Praktik. Jakarta: Salemba Humanika.

M. Hikmat, Mahi. 2011. Metode Penelitian Dalam Perspektif Ilmu Komunikasi dan Sastra. Yogyakarta: Graha Ilmu.

Nurjaman Kadar \& Umam Khaerul. 2012. Komunikasi \& Public Relations. Bandung: Pustaka Setia

Olii, Helena. 2007. Berita dan Informasi. Bandung: PT. INDEKS. 2010. Public Speaking. Jakarta: PT. INDEKS.

Ruslan, Rosady. 2016. Manajemen Public Relations dan Media Komunikasi. Konsepsi \& Aplikasi. Jakarta: Rajawali Pers.

Robert. 1996. Pelayanan Publik. Jakarta: PT Gramedia Pustaka Utama. 